\title{
Identifications, Articulations and Proportions in Practical Theological Interpretation
}

\author{
Professor Grant Macaskill, University of Aberdeen
}

\begin{abstract}
:
The task of theological interpretation should be shaped and regulated by an awareness of the issues at stake in theological method, and the debates surrounding this. Biblical scholars attempting to interpret the Bible theologically can often be naïve to the methodological shift that is required if the task is to be undertaken responsibly, and can pay inadequate attention to the distinctive identifications of the object of studye.g., as historical artefact or Word of God-that underlie the different methodologies of historical criticism(s) and theological interpretation(s). Biblical scholars who are principally trained in a historical-critical methodology focused on the justification or falsification of claims must understand that theological method is not merely concerned with truth and falsehood, but also with the architecture of theological claims, that is, matters of order, proportion, and articulation. At the same time, the biblical scholarly contribution cannot neglect the distinctive historical and creaturely identification of the biblical texts and their authors.
\end{abstract}

\section{Introduction}

In September 2015, I moved to the University of Aberdeen and gained a new set of collegial conversation partners, all interested in how the disciplines intersect on specific issues. The various dialogues that emerged from this happy situation led me to publish a number of works covering topics ranging from the doctrines of providence $^{1}$ and divine aseity ${ }^{2}$ to the theological evaluation of autism and its place

\footnotetext{
${ }^{1}$ Grant Macaskill, "History, Providence, and the Apocalyptic Paul," Scottish Journal of Theology 70 (2017), 409-226.
} 
within the life of the church. ${ }^{3}$ These works have sometimes involved scrutinizing significant debates in biblical scholarship using theological categories and insights, have sometimes been intended to show how the nomenclature and terminology is heuristically invaluable to the task of articulating the meaning of the biblical text, and have sometimes brought exegetical insights from biblical scholarship into dialogue with issues of practical theology. My highlighted word, "sometimes," calls attention to something that I consider important: theological interpretation is not one homogenous thing, but can involve a range of activities and interests, approached differently because we recognize the mutual relevancy of the disciplines.

The occurrence of the word "practical" in the title of this article is intended to reflect two points of critical significance. First, theological interpretation must actually practice the skill of interpreting theologically: that is, it must do some interpretation, and it must do this theologically. A common criticism of the theological interpretation movement (one made forcefully by Walter Moberly) ${ }^{4}$ is that it has often been locked in matters of prolegomena or theoretical hermeneutics, and has not actually reached the point of practice that is really needed to demonstrate the merits (or demerits) of these. Only by actually practicing what we preach can we

${ }^{2}$ Grant Macaskill, "Divine Aseity and Soteriology in the Gospel of John: The 'I AM' Sayings and Jewish Speculation on the Divine Name." Journal of Theological Interpretation 12 (2018), 217-241.

${ }^{3}$ Grant Macaskill. “Autism Spectrum Disorders and the New Testament: Preliminary Reflections," Journal of Disability and Religion 22 (2018), 15-41, and Grant Macaskill, Autism and the Church: Bible, Theology, Community. Waco: Baylor University Press, 2019.

4 "Although it seems accepted practice to write books about biblical interpretation that do not interpret the Bible, I am increasingly doubtful about the value of the exercise. Unless I am shown how the discussions of principle help enable recognition, or even production, of good and bad readings of the biblical text in practice, I can find myself wondering what difference it all really makes." Walter Moberly, "Review: Christopher D. Spinks, The Bible and the Crisis of Meaning," Journal of Theological Studies 59 (2008), 711. 
really test the value of our sermons. Second, the allusion to the discipline of practical theology is intended to remind us that this is not a merely academic activity, but one associated with the reality of living in the light of God and his work.

In what follows in this article, I turn back to what we might call methodology or prolegomena, but I do so in conscious reflection on the practice of theological interpretation that I have engaged in over these last few years. What I write is informed by the particular areas of theological interpretation that have been part of my experience and, consequently, will not touch upon a range of other areas of activity that might fall under the umbrella term of theological interpretation, such as the place of 'biblical theology' or of reception history.

\section{The Modern Problem of Disciplinary Specialization}

One of the most basic practical challenges that we face in the theological interpretive task is the degree to which we are highly specialized practitioners of particular subdisciplines, shaped by the history of their development, often specifically the microupheavals of recent decades, and have only a limited grasp of the cognate disciplines. As a broad macro-discipline, Divinity has been fragmented into sub-disciplines, but the fragmentation itself is not the only problem; rather, the substance of the problem is that practitioners of each have often retreated to the center of their particular fragment, to the bit that can be done without reference to its traditionally apposed disciplines, practicing it in a way that can be considered methodologically safe (especially for research esteem purposes). Biblical scholars do the historical or textual tasks that are central and distinctive to our discipline, perhaps drawing in other useful methodologies that might inform these, such as discourse analysis or social scientific criticism, but generally don't move from the center to the broken edges that ought to be reconnected with those of the theological disciplines. This is partly because we have been cautioned against losing our moorings at the methodological center of our fragment, and partly because we just do not have time for something that might seem extraneous to our main task. We are just too busy staying on top of whatever is the current big issue in our own discipline. 
I find this image of fragmentation to be a useful one for analyzing the problem that we are concerned with here, for as we seek to re-integrate the disciplines, we have to bear in mind that the fragments were originally different parts of a unified or integrated task; they were not, in other words, identical to each other. Integration is not the same as homogeneity; that's something else, something altogether less wholesome. Our attempts to bring fragments together are often frustrated by our lack of recognition that the other fragment is not the same as our own, or that the task before us does not involve melting the fragments into a new composite, but recognizing how it is that they can be brought together without losing the differences that allow them to complement each other, and properly to inform each other. The only way to overcome this, I think, is by conversation with people who occupy that other fragment.

\section{Identifications}

At the heart of such conversations is an identification of the task of each discipline and, I would suggest, the linguistics particular to it, which is the key to both the challenge and the opportunity. A brief discussion of this will help to clarify what I mean.

Systematic or dogmatic theologies are concerned to give a proper and orderly ecclesial or creaturely account of what has been disclosed to us of God and his works. This involves a recognition that Scripture itself is not orderly, but unruly and wild; it norms Christian tradition not as a body of treatise, but as a collection of historically conditioned genres, ranging from narrative to proverb, commandment to apocalypse. The theological task does not seek to tame this wildness, or to impose order upon it, but to respond in a way that discerns the order within the wildness (the ecology, we might say), that is attentive to the relationship of the elements rendered in the canonical whole, and that is itself properly ordered, in a way that befits the work of those who are being renewed in the likeness of the Logos. This involves careful selection of words to render particular truths, and a careful use of grammar or syntax to govern the use of these words. Because the task involves engagement not just with 
a given pericope or author, but with the 'canon' (which is an important theological category in its own right) this selection of words and grammar necessarily grapples with the range of meanings and associations that given words might have in the different parts of the canon; to slightly misquote John Barclay: 'grace may be everywhere, but it is not everywhere the same' ${ }^{5}$ a point that can be extended more widely to the lexicon of bible and theology. If we fail to recognize this, and subsume or assimilate the language of theology to the language of exegesis, which is generally shaped in quite an immediate way by the language of the text in front of us (I'll say more on this in a moment), then there will be problems. If, we fail to realize the properly synthetic character of theology, and the consequent shape of its internal linguistics and philology, we will fail to understand the nature of its relationship to the exegetical task. Words, sometimes the same words, will be used differently in each context. And if we are to develop any kind of facility with theological language, we need to spend some time with native speakers, the inhabitants of the fragment.

The discipline of practical (or pastoral) theology also involves a negotiation of language, as it bears on the task at hand. Here, the linguistic dimension is shaped to a significant extent by the challenge of analyzing contemporary realities not named and perhaps not even imaginable by the writers of Scripture: how does one speak Christianly or theologically of autism or nanotechnology? We can certainly not go back to the Scriptural texts in which these things are described and engage in exegesis, for there are no such texts. Instead, we are driven to engage with these words, and the concepts that they name, and to reflect on what difference it makes to speak of them while also speaking of the God who has disclosed himself to us. Often the practical application of the task is itself linguistic: it breaks into the language acts by which non-theological accounts of particular issues render the matters at hand and holds them to account.

This linguistic reflection takes us to one of the core elements that will run through what follows in this article. As biblical scholars, we are effectively trained to think of our exegetical activities, and the language by which we render these, as shaped by the identification of our object of study principally as an historical artifact. Our task, then, is somewhat akin to fracking: provided we apply the right machinery to the text, with the correct method, we will be able to extract its meaning. That

\footnotetext{
${ }^{5}$ Cf., John M.G. Barclay, Paul and the Gift (Grand Rapids: Eerdmans, 2015), 565
} 
meaning is then generally expressed using the words found in the text, or their translational equivalents, as we understand them to be used in the text. Certain models of theological interpretation, particularly that of a certain kind of biblical theology, assume that the theological task merely takes what we extract by this mechanical process and applies it to theological questions. ${ }^{6}$ Sometimes a notion of coherent biblical theology or salvation history is used to warrant such a move: trace the line of an idea through the Bible, relating it to an overarching narrative, and we can fairly immediately move to a statement of its theological significance. This, too, tends to be governed by a concept of interpretation that can be likened to fracking-it is 'exegesis' after all; good method should lead the meaning out of the text-and, as such, it assumes a particular kind of relationship to the text, one that sees the interpreter as over the text, dissecting it or breaking it apart in order to obtain something from or through it. Subtly, the text becomes a commodity, something to be mastered and possessed and its value is in giving us access to something else. If, however, we identify the text as the Word of God, as theologically we must, then we have identified it as something not to be possessed, but to be heard, to be listened to. And, crucially, the appropriate response to that Word-especially when it functions not as collection of isolated texts, but as a canon - is not necessarily to recite its own lexicon, but to identify the correct form of words to speak faithfully of what we find there and to locate it with respect to our tasks.

Importantly, then, we have a set of diverse identifications that need to be factored into the integrative practice of theological interpretation-identifications of different tasks and different modes of language at use within them-and central to all of these is the identification of the Bible, as it functions within our task. Here, though, is the point critical to our reflections in this particular volume: these identifications are not mutually exclusive. The Bible is a historical artifact, emerging from particular periods of time. It is entirely valid for some scholars to study it exclusively in such terms. Functionally, however, this does not exhaust its significance, and overlooks what for millions of people is its principal significance: that it is sacred Scripture. But if we choose not to adopt an exclusively historical-critical approach (bundling into that term

\footnotetext{
${ }^{6}$ This, for example, is precisely what N.T. Wright does in The Day the Revolution Began: Reconsidering the Meaning of Jesus's Crucifixion (San Francisco: HarperOne, 2016).
} 
the various ideological, literary or social scientific approaches), it is simply inappropriate to ignore its historical particularities. In fact, it is basically inattentive to the character of Scripture and to what has, in some traditions, been labeled its organic inspiration. This stands a criticism of the kind of banal examples of theological interpretation that can easily be identified, which effectively bypass the matters of historical importance. ${ }^{7}$ It also opens the way for biblical studies, provided it is attentive to the linguistic negotiation required, to speak back to the appropriation of biblical texts in the theological task. Sometimes this appropriation simply cannot be squared with how the text is most obviously read in relation to the historical particularities that are part of its own witness, and this must be asserted. But we must be careful in doing so not to elide the differences between the disciplines that might warrant the moves made theologically.

\section{Articulations}

The disciplines of theology operate with an identification of the object of study-the Word of God in Scripture - that prevents any constituent part from being considered the terminal point of interpretation. The exegesis of any given text must be related to the canonical whole, in a way that is regulated by a doctrinal system which is always (in principle, at least), subject to change if it cannot accommodate the scriptural testimony. This is different from the historical task normally performed by biblical scholars and also, it is worth noting, from the literary one. Literary studies, such as narrative criticism, are not the same as canonical engagement, and neither are those biblical theologies that conceive 'canon' simply in terms of a unifying overarching narrative.

\footnotetext{
${ }^{7}$ Note the comments offered by Markus Bockmuehl in "Bible vs. Theology: is 'Theological Interpretation' the Answer?” Nova et Vetera 9 (2011), 27-47. In a memorable paper delivered at the Society of Biblical Literature Annual Meeting in 2008, a forerunner to the article just noted, Bockmuehl likened the blandness of some theological interpretations to recipes for clam chowder that observed the geographically enforced prohibition of certain ingredients.
} 
For biblical scholars, in particular, it is important to recognize that much of this task is concerned to identify the relations between the elements and order them rightly, ensuring that the correct elements are given controlling significance over others (such as the way that the doctrine of God properly controls the doctrine of scripture, the significance of which must be considered derivative) ${ }^{8}$ This task also involves the recognition of articulations between doctrines, the neglect of which will lead to the distortion of theological assertions.

One example of this that I have developed recently is the doctrine of providence. ${ }^{9}$ Providence is the term that labels the acting of God upon his creation, as he works to bring creatures, and the creation as a whole, to their telos. While the doctrine has been subject to multiple definitions, many of which are notoriously problematic, it is nevertheless found throughout and across the theological traditions where, typically, it is 'distributed': that is, rather than being confined to one particular doctrine or area (e.g., theology or economy, creation or redemption), it is encountered across the systems, as it articulates with each doctrine. ${ }^{10}$ My own reason for considering the doctrine lies in some observations on the debate between Douglas Campbell and N.T. Wright over apocalyptic and salvation-history-in which both contributors see themselves to be developing good theology in a theologically responsible way. ${ }^{11}$ Both see themselves as theologically astute interpreters, arguing about the nature of God's

${ }^{8}$ See John Webster, 'The Dogmatic Location of the Canon', Neue Zeitschrift für systematische Theologie 43 (2001), 17-43.

${ }^{9}$ Grant Macaskill, "History, Providence, and the Apocalyptic Paul," Scottish Journal of Theology 70 (2017), 409-226.

${ }^{10}$ See the collection of essays in Francesca Aran Murphy and Philip G. Ziegler, The Providence of God: Deus Habet Consileum (London: T\&T Clark, 2009).

${ }^{11}$ For the positions of each, see N.T. Wright, Paul and the Faithfulness of God (London: SPCK, 2013); idem, Paul and His Recent Interpreters (London: SPCK, 2015); Douglas A. Campbell, The Deliverance of God: An Apocalyptic Re-reading of Justification in Paul (Grand Rapids: Eerdmans, 2010). The introductions to both studies usefully highlight the convictions of each author on the theological revelance of their approach. There have also been several public debates between the two, with the most celebrated of these taking place at Duke Divinity School and at the Annual Meeting of the Society of Biblical Literature in San Diego, both in 2014. 
historical dealings with creation and with Israel and how these relate to the gospel, yet neither make use of the word that the traditions have used to speak of these dealings: providence. Presumably, the lack is to be traced to the obviously non-Pauline character of that word, though they are happy to use plenty of other words not encountered in Paul. Had they used the word 'providence', the conversation between them would have been quite different, since its distribution across the theological systems, and its articulation with other doctrines, would have required them to talk about the unexamined doctrines, or unarticulated assumptions, at work in their scholarship. Talk of God's providence sets limits on the ways that we might speak pejoratively about the history of Israel or the Law, contra much of Campbell's rhetoric; but it also demands that we consider providence as always, everywhere, mediated by the Incarnate Son, by whom and for whom all things were made and in whom they hold together. That is, considered through the doctrine of providence, the stories of creation and of God's dealings with Israel are conditioned by the Christ event, and not vice versa, except in particular qualified senses. This, I think, is quite at odds with the conceptualizing of salvation-history in Wright.

If we get this wrong, if we fail to invoke the correct doctrinal term in the correct way, then the move is disastrous for practical theology. To stay with the example above, Campbell's reading of Paul leaves no room for the apostle to sing 'How I love your law ... your statutes make me wiser than my enemies' (Ps 119:97-8) and no room for any believer whose theology is shaped by Paul to find moral or pastoral instruction in the Old Testament (he does not discuss those points when Paul does precisely this, as in 1 Cor 9:9 or 1 Corinthians 10:1-11). ${ }^{12}$ Wright meanwhile develops an account of creational order, and its place in redemption, that does not begin with the priority of the incarnation, but rather makes the incarnation a stage in the recovery of the original vocational state of man as the image of God. But what do we do with those who are prevented from fulfilling that vocation because of their disabilities? Classical theology can deal with this by understanding our image-bearing

${ }^{12}$ On the latter, see my "Incarnational Ontology and the Theology of Participation in Paul,' in Kevin J. Vanhoozer, Constantine Campbell and Michael Thate, eds., 'In Christ' in Paul: Explorations in Paul's Theology of Union and Participation, WUNT II, Tübingen: Mohr Siebeck, 2014, 87-102. 
as an analogical participatory condition and by accounts of providence that ascribed a distinct telos to each creature, ${ }^{13}$ Wright's, like many contemporary accounts, requires a different idealism, one linked to the competency of the individual to fulfil the universal Adamic vocation.

I use this example to highlight that an important part of the theological interpretive task involves recognizing that the articulations between doctrines have an important controlling effect on our discourse as we seek to move beyond the specifics of any pericope or author and to make a serious theological claim. As we move to such claims, we need to allow doctrinal articulations to inform and constrain what we say. While I have used providence as an example of this, a more important and widely found problem is constituted by the dislocation of Christology from its moorings within trinitarian theology proper. Ingolf Dalferth highlights some of the shifts that took place in the $19^{\text {th }}$ century, particularly within Anglican theology, and specifically through the Oxford Movement, by which the incarnation became "the all encompassing paradigm of theological thinking," a move that continues to shape the subsequent modern theological landscape. ${ }^{14}$ Many who see themselves as theologically careful, because they prioritize christology or incarnation, may in fact be theologically careless, for their christology is not located properly with respect to the doctrine of God.

But how can we, as biblical scholars whose theological formation is compromised by the disciplinary specialization I mentioned above, acquire a meaningful grasp of such doctrinal articulations, of a kind that will allow us to be sensitive to them and, indeed, to sensitively speak back to them? Let me make two practical suggestions.

The first is, very simply, that we need to engage in conversations with theological scholars. Those conversations are, ideally, in the form of genuinely interpersonal or collegial interaction, but will also involve reading theological works. For those who do not enjoy the privilege of having colleagues who are willing to engage in such conversation, or whose collegial environment is less, well, "collegial," the latter may be all that you have.

\footnotetext{
${ }^{13}$ I observe this point in Macaskill, Autism and the Church, 81-6.

14 Ingolf Dalferth, Crucified and Resurrected: Restructuring the Grammar of Theology (Grand Rapids: Baker, 2015), 3.
} 
I use the word "conversations" here, rather than "dialogue" for good reason: dialogue implies that there is an attempt to reach agreement or to resolve differences, while conversation is more open, allowing differences to stand, and allowing discussions to move more broadly between particulars and frameworks. Conversation allows us to gain a more rounded familiarity with the other, while dialogue will be constrained by the issues at stake. Mapped onto our engagement with theological writing, "conversation" suggests a mode of reading that wants to "get to know" the field, that reads it for its own sake and in acknowledgement of its own value, rather than merely as something connected to our latest problem-solving exercise. Put bluntly, if we want to be good theological interpreters, we need to read more good theology, and to go beyond the superficial points of contact.

The second suggestion is that we think seriously about how to incorporate this into our teaching. This can, at once, be a modest response to our perception that the disciplines are fragmented and that the next generation needs help to put them back together, and, at the same time, be an opportunity for conversation between colleagues (an exercise in teaching-led research). When I was in St Andrews, I cotaught a course on Christology and Pneumatology with Ivor Davidson and it was a scintillating experience of such conversation; the co-teaching was done precisely through un-mapped conversation that was anchored by common engagement with scriptural texts and scholarly articles. Elements of it fed through to my books on union with Christ and now on intellectual humility and that single co-taught course had an immense impact on my awareness of theo-logic.

\section{Proportions}

If articulations are an important part of theological method, so too are proportions. The difference between a good theology and less good theology is not always a matter of the correctness or incorrectness of propositions, or of decisions on either/or matters, but is often about whether we have located the issue properly in relation to other doctrines and have dealt with it in correct proportion. If our doctrine of sin occupies the same proportion as our doctrine of God, is there a problem with our theology? More subtly, perhaps, if our doctrine of Scripture has a similar such 
proportion, is there a problem? The point is a particularly important one for us to be aware of as biblical scholars, for at least two interwoven reasons.

First, we can easily give a dominating proportion to elements that we encounter or detect in the text in front of us (often in isolation from the rest of Scripture) and can then seek to make that do more theological work than it ought to. This may be true of something like Roman Imperial Power, which would theologically best be cast as a particular sub-species of idolatry and then lined up properly in relation to the doctrine of God and the demands of trinitarian monotheism. This is a fruitful way to reflect on, for example, Revelation 13. If it is not properly so proportioned, we end up with a theme that functionally governs christological statements (seeing the representation of Christ in the New Testament as polemically directed against Roman Imperial Power, rather than as a function of monotheism with implications for this particular instantiation of idolatry).

More subtly, Christology can come to have a proportion that eclipses other aspects of trinitarian doctrine and obscures its articulations with these. This, indeed, is one of the deepest problems in contemporary New Testament scholarship, even among those who are theologically interested; pneumatology as a category of monotheism has received much less attention than it should have, and the question of what God is in himself (theology proper, as distinct from economy) has similarly been neglected. This is especially problematic, because both elements are actually more important to the New Testament, proportionately, than is generally reflected in scholarship.

Second, those who engage in the theological interpretive task within the evangelical tradition - and I suspect a number of us would identify in such terms, even if broadly-will often move very quickly from the exegesis of a text to the theological assertion, without reflecting on the theological task more fully. In such a situation, we are in danger of giving particular matters a proportion that effectively causes them to have a certain gravitational mass that controls other issues in a distortive way. These proportions, moreover, may reflect the fact that the issues have come to have such scale in our recent ecclesial traditions.

Let me give two examples, highlighting along the way that our ascription of proportion has effectively eclipsed other relevant considerations and turned the issues in question into "either-ors," rather than "both-ands." Neither will require much explication. The first is Christology, and particularly the defense of high Christology, 
the identification of Jesus as God. For obvious reasons, this has been a battle that many of us have been concerned to fight, in order to defend what we consider to be a sine qua non of Christian theology: that our Savior is properly to be known as the incarnate God. But such is the proportion that we have given to this that elements in the New Testament (or scholars who comment on them) that are more concerned with the assertion of Jesus' humanity are often underplayed or, in the case of the scholars, attacked. The reception of David Moffitt's study of the atonement in Hebrews has been one such example: Moffitt was widely criticized in certain circles for what was seen to be a denial of the divinity of Jesus, simply because of his assertion of the soteriological place of Jesus' humanity. ${ }^{15}$ I experienced something similar when I gave a paper on Colossians 1:15ff in the States last year and a reviewer suggested that I was an Arian, because I had highlighted that the Son-as he is represented in that text - has a creaturely nature which is essential to his mediatorial role. The divinity of Christ has taken on a proportion that wrongly eclipses or distorts the humanity; this is a long way from classical two-natures Christology and its assertion, "the unassumed is the unhealed." 16 The second example is atonement and this one, I think, cuts both ways. The defense of penal substitutionary accounts-which do, I think, find support in the New Testament - is typically made in an exclusive way, but so, too, are the alternatives. The possibility that we may have something that involves a range of complementary but different images of exchange-including blame-taking, but also including healing and purification-has been buried in much of the discussion. One we recognize the presence of a range of images, which may be overlaid (as they are in Isaiah 53), the real question becomes one of proportion. I am an evangelical and want to affirm the place of penal elements in the New Testament representation of atonement (particularly in 1 Peter) but, honestly, I think it is a relatively small and not necessarily central place; moreover, the penal substitutionary idea is itself a particular

${ }^{15}$ See, for example, Aubrey Sequiera, "Atonement and the Logic of Resurrection in the Epistle to the Hebrews (Review)," in Credo 4 (2014). Available online at: https://credomag.com/2014/01/atonement-and-the-logic-of-resurrection-in-theepistle-to-the-hebrews-review/

${ }^{16}$ This statement is found in Gregory of Nazianzus, Epistolae 101, but the concept that it articulates is found more widely in Patristic theology, with analogues in Irenaeus and Athanasius, among others. 
metaphor, deployed to render the significance of what the texts say. At the same time, I want to assert that atonement can never be reduced to ritual or cultic issues; these need to be balanced by reflection on the place of, e.g., therapeutic or reconciliatory language in the New Testament.

\section{Concluding Reflections: Conversation as a Two-Way Activity}

These last points take us to the issue with which I want to close this paper. Up to this point, I have really been speaking about how biblical scholars overcome their lack of facility with theological scholarship, in order to engage in theologically responsible interpretation. I want to close by flipping this point and highlighting that theologians need to listen to biblical scholars in this conversation, too. Once the considerations highlighted up to this point have been acknowledged, biblical scholars who are alert to them can deeply enrich the theological task. What can we identify by way of articulations between doctrines in the texts of the Bible, and how might this speak to the theological formulations? What proportions do the various doctrinal elements have in the Bible and how might this control theological formulations? If the Bible is indeed the normative text of Christian theology, how does it speak into such issues of order, articulation and proportion? How does it disrupt properly a theological task that might have drifted too far from it? If we find a range of images for salvation in the New Testament, how does this speak to our concept of atonement? How does the representation of the church in Paul and in James speak to our ecclesiology? Do these call us to jettison ideas because they are entirely at odds with what we find in the bible, or do we more modestly consider the proportions to be in tension. To what extent can we engage in an analytic theology, when the normative text often works by collaging imagery, rather than proposing logics?

Reaffirming the place of the Bible in these ways can help to expose the extent to which modern theology suffers from the same problems as modern biblical studies; often dislocated from its moorings, both in scripture and in tradition, it is itself subject to the problems of disproportion and disordering. Its own linguistics are not adequately attentive to those of the biblical text. Re-attaching the fragments, and allowing them to contextualize and inform one another properly, may not immediately solve this problem, but it does begin to expose it. Part of this, of course, may involve 
one particular common area of study that I have said nothing of so far, which is the place that historical theology, reception history and the commentary traditions occupy in the task of theological interpretation. This, I'm sure, will be dealt with elsewhere in the conference, but we can note here that the study of receptions and commentaries from the pre-modern period can help to illustrate what the negotiation of the distinct tasks of treatise, sermon and commentary looked like for those who were less disintegrated than we are. They invite reflection on how they make different moves than we might make, both as theologians and biblical scholars, and why this is the case. I would suggest that similar insights can also be gleaned from the better examples of contemporary preaching, from well-formed pastors who reflect seriously on how the Word of God might speak to them and to their congregations today.

One last point can be made on this representation of the task as a two-way conversation. As with all conversations, the productivity depends to no small extent on the character and temperament of the participants, and the task is successful only if it is attended by critical generosity and humility. Without naming anyone, I think we are all aware that there are some scholars who have engaged with each other across the disciplinary bounds without real generosity: they are aggressive, defensive, dismissive and, frankly, arrogant. They often see their activity as one that makes and defends actual theology, in the sense that they really are saying things that are true of God, and there is no charity in their engagements with the disciplinary other. Even if it should be the case that they are correct in their assertions, their mode of interaction is one that commodifies the intellectual good and, indeed, commodifies Scripture. It ceases to be the living voice that is - and must always be-the one speaking normatively into our conversation. So, I will closec with these words from Luke Timothy Johnson and suggest that they speak to both sides of the biblical and theological task equally:

We must also let go of any pretense of closing the New Testament within some comprehensive, all-purpose, singular reading which reduces its complexity to simplicity. Whether we call it New Testament Theology, or Narrativity, or Existential Hermeneutics, or something else, we must recognize our attempts to reduce multiplicity to unity, to nail down some central, single, encompassing meaning in the New Testament that is also and above all portable, as attempts precisely at closure. We must recognize our tendency to 
seek a stable package of meaning that we can then apply to other situations or fit within out systematic theological constructs, so that, ideally, we need never really read the texts again. ${ }^{17}$

${ }^{17}$ Luke Timothy Johnson, Scripture and Discernment: Decision-Making in the Church (Nashville: Abingdon, 1983), 55. 